\title{
Who Owns the Preah Vihear Temple? A Thai Position
}

Monticha Pakdeekong*

\section{Introduction}

An outstanding masterpiece of Khmer architecture, the Temple of Preah Vihear is situated on a promontory of the Dangrek mountain range, which straddles the boundary between the Kingdom of Thailand and Cambodia. The Temple was listed by Thailand as being situated in Bhumsrol village, Bueng Malu sub-district, in the Kantharalak district of the Srisaket province in eastern Thailand. The Temple is composed of a series of sanctuaries linked by a system of pavements and staircases on an 800 metre north-south axis rising up the hill towards the sanctuary.1

Dating back to the early eleventh century, the Temple of Preah Vihear has been situated on a mountain of religious significance. There was a process of expanding the Hindu faith at that time which was supported by the Khymer king, who allowed the Temple to be sacrificed as a Hindu place of worship. There was no issue of sovereignty promulgated over the land. The Temple of Preah Vihear was situated on the boundary between the Kingdom of Thailand and Cambodia and it was the centre of a grand community. Both Cambodians and Thais enjoyed the Temple for religious purposes, conducting trade, and it served as the centre between the high-Khmer and the lowKhmer communities. The issue relating to the east and west territory was not taken into account.

This article discusses two issues essential to understanding the controversy between the Kingdom of Thailand and Cambodia over the sovereignty of the land surrounding the Temple of Preah Vihear. First, the Decision of the International Court of Justice on June 15, 1962,2 did not, as claimed by Cambodia in 1959, determine any land boundary

\footnotetext{
Lecturer, Faculty of Law, Chiangmai University, Thailand. LL.B. (Hons/Chiangmai), LL.M. (Chulalongkorn)

1 Temple of Preah Vihear: Brief Description, World Heritage List, available at http://whc.unesco.org/en/list/1224 (last visited on Jan. 12, 2009).

2 Temple of Preah Vihear (Cambodia v. Thailand), 1962 I.C.J. 6 (June 15, 1962), available at http://www.icjcij.org/docket/ files/45/4871.pdf (last visited on Jan. 10, 2009).
} 
between Siam and Cambodia. Second, the decision adopted at the 32nd Session of the World Heritage Committee ${ }^{3}$ raises a matter of critical concern to Thailand regarding the unresolved border dispute in the area surrounding the Preah Vihear Temple.

\section{A. The Decision of the International Court of Justice (ICJ): Status and Judicial Consequences}

The conflict between Siam and Cambodia over the Temple of Preah Vihear was related to an ambiguous frontier line constituted by the provisions of the 1904 and 1907 SiamFranco treaties. The application of the Treaty of February 13, 1904, established that the boundary in the eastern sector of the Dangrek mountain range was to follow the watershed line and that would place the Temple in Thailand. The Treaty of February 13, 1904, Article I reads as follows:

The frontier between Siam and Cambodia starts, on the left shore of the Great Lake, from the mouth of the river Stung Roluos, it follows the parallel from that point in an easterly direction until it meets the river Prek Kompong Tiam, then, turning northwards, it merges with the meridian from that meeting- point as far as the Pnom Dang Rek mountain chain. From there it follows the watershed between the basins of the Nam Sen and the Mekong, on the one hand, and the Nam Moun, on the other hand, and joins the Pnom Padang chain the crest of which it follows eastwards as far as the Mekong. Upstream from that point, the Mekong remains the frontier of the Kingdom of Siam, in accordance with Article I of the Treaty of 3 October 1893.

Eventually, on March 23, 1907, the Siamese concluded the boundary treaty with Franco, which established the Franco-Siamese Mixed Commission for the purpose of delimiting that frontier. The Mixed Commission mapped the frontier region and the Cambodian Government used this as a reason to argue to the International Court of Justice that the frontier line, as indicated on the map below, showed the Temple to be located in Cambodian territory. 


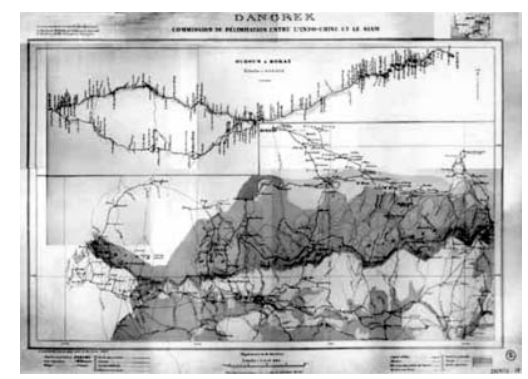

Map 1: Representing the frontier line in 1908

(designated by the International Court of Justice as the Annex I map)4

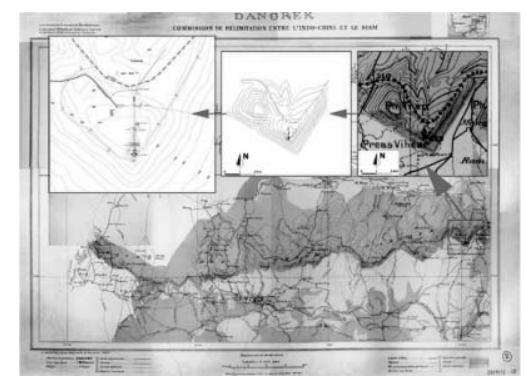

Map2: Area of the Temple of Preah Vihear in the Dangrek range of mountains5

On October 6, 1959, the case concerning the Temple of Preah Vihear was brought to the ICJ by Cambodia's Unilateral Application. Cambodia requested judgments in five Final Submissions:

a. "To adjudge and declare that the map of the Dangrek sector (Annex I map to the Memorial of Cambodia) was drawn up and published in the name and on behalf of the Mixed Delimitation Commission set up by the Treaty of 13 February 1904, that it sets forth the decisions taken by the said Commission and that, by reason of that fact and also of the subsequent agreements and conduct of the Parties, it presents a treaty character;

b. To adjudge and declare that the frontier line between Cambodia and Thailand, in the disputed region in the neighborhood of the Temple of Preah Vihear, is that which is marked on the map of the Commission of Delimitation between IndoChina and Siam (Annex I map to the Memorial of Cambodia);

4 Kingdom of Cambodia, 4 The Temple of Preah Vihear: Proposed for the inscription on the World Heritage List (UNESCO) (COUNSEL OF MINISTERS eds., 2008), available at http://www.preah-vihear.com/PreahVihearProposalbyRGC.pdf (last visited on Jan. 12, 2009).

5 Id. at 8. (Extrapolation from the map recognized by the International Court of Justice on June 15, 1962). 
c. To adjudge and declare that the Temple of Preah Vihear is situated in territory under the sovereignty of the Kingdom of Cambodia;

d. To adjudge and declare that the Kingdom of Thailand is under an obligation to withdraw the detachments of armed forces it has stationed, since 1954, in Cambodian territory, in the ruins of the Temple of Preah Vihear;

e. To adjudge and declare that the sculptures, stelae, fragments of monuments, sandstone model and ancient pottery which have been removed from the Temple by the Thai authorities since 1954 are to be returned to the Government of the Kingdom of Cambodia by the Government of Thailand." 6

The Court adjudicated the conflict between Thailand and Cambodia over the Temple of Preah Vihear on June 15, 1962:

a. By nine votes to three, finds that the Temple of Preah Vihear is situated in territory under the sovereignty of Cambodia;

b. [It] finds in consequence, by nine votes to three, that Thailand is under an obligation to withdraw any military or police forces, or other guards or keepers, stationed by her at the Temple, or in its vicinity on Cambodian territory;

c. By seven votes to five, that Thailand is under an obligation to restore to Cambodia any sculptures, stelae, fragments of monuments, sandstone model and ancient pottery which might, since the date of the occupation of the Temple by Thailand in 1954, have been removed from the Temple or the Temple area by the Thai authorities. ${ }^{7}$

In reaching the decision, the Court refrained from deciding on Cambodia's Submission 1 and 2 which were the status of the map of the Dangrek sector scale 1/200,000 (Annex I map) and the corrections of the frontier line indicated on it (Annex I map). The Court did not rule on the exact location of the boundary line between Thailand and Cambodia in the area. Hence, the Court did not rule that the map filed as Annex I showed the frontier line between Thailand and Cambodia. The Court held that:

Referring finally to the Submissions presented at the end of the oral proceedings, the Court, for the reasons indicated at the beginning of the present Judgment, finds that Cambodia's first and second Submissions, calling for pronouncements on the legal status of the Annex I map and on the frontier line in the disputed region, can be entertained only to the extent that they give expression to grounds, and not as claims to be dealt with in the operative provisions of the Judgment. 8

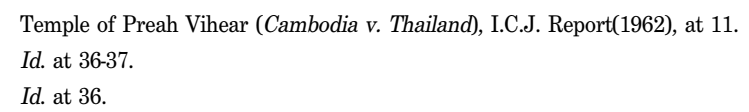


Thus, the Court ruled that the Temple belongs to Cambodia, however the Court did not rule on the land surrounding the temple, an area which remains in dispute. Subsequently, Thailand took a number of steps and made certain reservations with respect to the Court's ruling.

First, according to the Statute of the International Court of Justice Article 59 "The decision of the Court has no binding force except between the parties and in respect of that particular case." As a member of the United Nations (UN), Thailand accepted the decision of the Court, turned over the Temple to Cambodia, withdrew its troops stationed at the temple, and withdrew the Thai tricolor national flag from the disputed area. ${ }^{9}$ However, the judgment has no binding force over other states or organizations including UNESCO which proposed including the Temple of Preah Vihear on the World Heritage List.

Second, the Thai government registered a protest against the decision of the Court and reserved its right to recourse in the future if Thailand discovered new facts and law in its favor as codified in Article 61 of the statute. 10 In addition, the Thai government dispatched a note to formally inform the UN Acting Secretary-General on July 6, 1962, that "His Majesty's Government desires to make an express reservation regarding whatever rights Thailand has, or may have in the future, to recover the Temple of Phra Viharn by having recourse to any existing or subsequently applicable legal process, and to register a protest against the decision of the International Court of Justice awarding the Temple of Pra Viharn to Cambodia." 11 However, for decades since the court ruling, the case has never been referred to the Court again either by Thailand or Cambodia. That means the Thai authorities have never used Article 6012 to ask the Court for clarification of the meaning or scope of its judgment. Nonetheless, Thailand reserved the

9 Note to U.N. Acting Secretary-general No. (0601) 22239/2505 Ministry of Foreign Affairs, Bangkok, July 6, B.E. 2505 (1962).

10 Article 61 of the ICJ Statute of states:

1. An application for revision of a judgment may be made only when it is based upon the discovery of some fact of such a nature as to be a decisive factor, which fact was, when the judgment was given, unknown to the Court and also to the party claiming revision, always provided that such ignorance was not due to negligence.

2. The proceedings for revision shall be opened by a judgment of the Court expressly recording the existence of the new fact, recognizing that it has such a character as to lay the case open to revision, and declaring the application admissible on this ground.

3. The Court may require previous compliance with the terms of the judgment before it admits proceedings in revision.

4. The application for revision must be made at latest within six months of the discovery of the new fact.

5. No application for revision may be made after the lapse of ten years from the date of the judgment.

11 Supra note 9 .

12 The Statute of the International Court of Justice, Article 60 stipulates that "[t]he judgment is final and without appeal. In the event of dispute as to the meaning or scope of the judgment, the Court shall construe it upon the request of any party." 
right to reclaim the Temple because Article 60 of the statute has no limitation period. Thailand was concerned that the decision of the Court may have caused further loss of Thai territory to Cambodia in respect of the land surrounding the Temple area, or the so called "overlapping area."

\section{The Unresolved Border Dispute relating to the Area Surrounding the Temple of Preah Vihear and the inclusion of the Temple on the UNESCO World Heritage List: The Thailand's anxiousness}

World Heritage sites are protected under the "Convention Concerning the Protection of the World Cultural and Natural Heritage" of 1972 (Convention), adopted by the United Nations Educational Scientific and Cultural Organization (UNESCO) to ensure the protection and conservation of cultural and natural heritage. 13 Any sites which are proposed for listing under the Convention have to be considered as of "Outstanding Universal Value" which means to be so exceptional as to transcend national boundaries and to be of common importance for the present and future of all humanity. 14 In the past, the inclusion of sites on the World Heritage List was not regarded as a necessity unlike it is today.

The ancient Hindu Temple of Preah Vihear is considered to be a priceless inheritance over many generations. The temple holds an important place in the history of Thailand's relationship with Cambodia. Especially after peace had come to this region, countless Thais and Cambodians have valued the opportunity to experience the architectural and historical beauty of the Temple and its surrounding ancient remains. Accordingly, Thailand acknowledged that the temple has an outstanding value to humanity and that it is right for Preah Vihear to be included on the World Heritage list:

"The State Party of Cambodia and the State Party of Thailand are in full agreement that the Sacred Site of the Temple of Preah Vihear has Outstanding Universal Value and must be inscribed on the World Heritage List as soon as possible." 15

Subsequently, without any consultation with the Thai government, recognizing that Thailand has repeatedly expressed a desire to participate in a joint nomination of the Temple of Preah Vihear and its surrounding areas or a transboundary nomination that

\footnotetext{
ABOUT WoRld HeRITAGE, available at http://whc.unesco.org/en/about (last visited on Jan. 12, 2009).

Id.

5 Draft Decision 31 Com 8B.24, Decisions Adopted at the 31st Session of the World Heritage Committee 155 (Christchurch 2007), available at http://whc.unesco.org/en/sessions/31COM/documents (last visited on Jan. 12, 2009).
} 
would require the consent of both Thailand and Cambodia, the Cambodian government unilaterally proposed the inclusion of the Temple of Preah Vihear on the World Heritage List at the 32nd Session of the World Heritage Committee in Quebec City, Canada.16 Cambodia's application to UNESCO was a matter of critical concern to Thailand due to the unresolved border dispute relating to the area surrounding the Preah Vihear Temple. Adhering to the frontier line indicated on the map filed in the portfolio submitted to the World Heritage Center (UNESCO-Paris) in order to comply with the Operational Guidelines of the Kingdom of Cambodia for the Implementation of the World Heritage Convention, prepared by the Ministry of Culture and Fine Arts of Cambodia, the frontier line would have trespassed over Thai territory and resulted in an overlapping territorial claim of 4.6 square kilometers surrounding the Temple of Preah Vihear. This caused difficulties over Thailand's sovereignty since this area had not yet been surveyed and demarcated by the Thai-Cambodian Joint Commission on Demarcation for the Land Boundary (JBC) between Thailand and Cambodia. Likewise, the ICJ had never adjudicated over this matter.

In 1962, the ICJ refrained from deciding the status of the map in Annex I to Cambodia's submission relating to the frontier line between Thailand and Cambodia. However, Cambodia unilaterally used this map to delimit the border area of the Temple of Preah Vihear despite the fact that the map in Annex I was not approved by the Court. The map was not the work of the Mixed Commission and the map was never formally approved by the Franco-Siamese Mixed Commission because it ceased to function before the map was produced. Furthermore, the frontier line indicated on the map is inconsistent with the express terms of Article 1 of the 1904 Treaty, i.e., the line of the French made map diverged from the watershed line. Moreover, the map and the line indicated on it were nonetheless accepted by the parties. As a result, the map had no binding character.

Contrarily, in Thailand's view, based on the pre-existing Franco-Siamese bilateral Treaty of February 13, 1904, it seems clear from the Franco-Siamese Mixed Commission that the frontier line along the Dangrek mountain range was to follow the line of the watershed. Because this was accepted by both parties of the 1904 Treaty, it is clear that the watershed line is the precise frontier line between Thailand and Cambodia because neither party has ever derogated from the treaty and are thus bound by its terms. Hence, Thailand still retains sovereignty over the land surrounding the Temple area and there is no overlapping territorial claim in relation to it.

One of the intentions of the 1972 Convention is to avoid conflicts and contestations between states. Article 11 paragraphs 3 stipulates that “...The inclusion of a property 
situated in a territory, sovereignty or jurisdiction over which there is a claim by more than one State shall in no way prejudice the rights of the parties to the dispute." It should be noted that the World Heritage Committee overlooked the fact of the unresolved border dispute between Thailand and Cambodia with respect to the area surrounding the Temple of Preah Vihear. Because no buffer zone was proposed in registering the Temple of Preah Vihear, where the entire vicinity is included in the Thai assets, a problem has been created. It is necessary to establish a core zone and a buffer zone according to paragraph 103 of the Operational Guidelines for the Implementation of the World Heritage Convention. 17 Hence, administrative measures are now required to prevent the construction of any buildings within the vicinity of the Preah Vihear Temple.

However, the most crucial issue relating to the case of the Preah Vihear Temple is not only the establishment of a buffer zone to protect the temple, but also to deal with the integrity of Thailand's border itself. Therefore, the development of a Full Management Plan for the property by Cambodia will not only cover the Temple of Preah Vihear but will also swallowed up a large unresolved border dispute relating to the 4.6 square kilometers surrounding the temple and some parts of Preah Vihear National Park located in Srisaket and Ubonrachatanee provinces of eastern Thailand which may now fall under Cambodian sovereignty. In doing so, the full value of the property and its surrounding area can be realized. Besides, the decision of the World Heritage Committee over the Temple of Preah Vihear is not practical because subsequent measures to be taken by either Cambodia or any third party over this area in Thai territory cannot be carried out without Thailand's consent as a key stakeholder.

Taking into account the above considerations, the Thai Government had sought to postpone the listing of the Temple of Preah Vihear at the 32nd session of the World Heritage Committee so that both countries could co-operate on the joint nomination of the Temple and its surrounding areas. However, this was ineffective because on July 7, 2008, the Sacred Site of the Temple of Preah Vihear was included on the World Heritage List, at the unilateral request of Cambodia.

\section{Conclusion}

The Kingdom of Thailand and Cambodia have changed over time into modern states. However, there are some elements of the historic states which remain unaltered. One of

17 UNESCO World Heritage Centre, Operational Guidelines for the Implementation of the World Heritage Convention, Rule 103, available at http://whc.unesco.org/archive/opguide08-en.pdf (last visited on Jan. 12, 2009). 
those elements is the issue of the border. It is a fact that a modern state requires a certain legal border. However, the issue of the exact boundary is hard to discern. The two countries believed that there was an evident border between them since the delimitation of it by France a hundred years ago. But in reality, the issue was always open to argument.

In a world of modern states, where countries depend on one another, economic conflicts, in particular, tend to be avoided where economies are evenly balanced. Economic considerations drive and limit other relations. If the two countries can divide their economic advantages equitably, other issues become less important. In the case of the Kingdom of Thailand and Cambodia it is quite clear that even if the problem was an issue of history and the border, by keeping in mind the mutual advantages of economic co-operation the two countries can maintain their good relationship. 